\title{
EDUVELOP
}

Journal of English Education and Development

Volume 1, No. 1, September 2017

ISSN 2597-713X (print)

ISSN 2597-7148 (online)

\section{CONTENT ANALYSIS SPEAKING MATERIALS IN ENGLISH TEXTBOOK BASED ON 2013 CURRICULUM FOR THE FIRST GRADE STUDENT AT VOCATIONAL HIGH SCHOOL}

\section{English Education Department, Faculty of Social and Political Science West Sulawesi University}

\author{
Address. Jl. Prof. Dr. H. Baharuddin Lopa, SH., Majene Regency,
}

West Sulawesi,Indonesia

Telp. +6285255383848 E-mail: keenadin@gmail.com

\begin{abstract}
This research aimed to analyze Speaking material in English textbook based on 2013 Curriculum for The First Grade Student at Vocational High 4 Makassar. The research method of this research was qualitative descriptive. The object of this research consists of English textbook and focus with Speaking material for the first grade based on 2013 Curriculum. The sample of the research was taken by using Checklist. To know how the relevancy the English textbook with 2013 curriculum that have been dealing with government. The researcher using 2 checklist the first was table to know the relation between speaking material in syllabus of 2013 curriculum and the second was table documentary checklist table to know how the relevance of materials to the curriculum criteria, and the result of the research showed by percentages. Having analyzed the data and the rubric scoring tabulation of this research, it was found that the degree of suitability of "Buku Bahasa Inggris" an English text book used by First grade students of Vocational High School was 75\%. The Researcher concluded that the textbook were logic and can be implemented as a learning source in the classroom. Although it still needs some revision to make it better. During the researcher doing this research, actually the researcher does not face a problem, because the researcher just analyzing and collecting the data by checklist so, the researcher could does this research have done.
\end{abstract}

Keywords: Content Analysis, English Textbook, Speaking Materials, curriculum 2013

\section{INTRODUCTION}

Language is communication for all people. As a human to interact with other people have to use Language. It proves that in general, human beings are social creatures who need each other. As social human the thing importance of language includes all of the aspects. It means that, language is used for communication. Many languages in the world, each country have a language that use as a local communication for sharing with other people, but there is a one of the most using English language. English is an important means of communication which is used in many countries in the world. English is the most important language because had to be an international language in the world. All of the countries admit it. So that's why the student have to learning English. In English language there are four language skills; listening, speaking, 
reading and writing. Those four language skills LITERATURE REVIEW

are component in English language, as A number of studies had been conducted in substance in English Teaching. order to investigate content analysis English Douglas Brown (2004) according to Speaking Textbook. First, Niken Wahyuningsih (2014) is a productive skill that can be directly and An Analysis of Reading Materials in Textbook empirically. It means that speaking one of the English in Focus For Grade VII Junior High most important skill that can support ability in School Published by Department of National English language, when the researcher want to Education This research talked about analysis of take this research. The researcher has been reading materials in the textbook and only interview the teacher at Vocational High focused on the reading skills, Second School 4 Makassar on April and from that SitiSolichatun (2011)Content analysis of interview had been gotten some information reading materials in English on Sky Textbook from the teacher, if the weakness of the for Junior High School Published by IAIN students is Speaking skills. The teacher thinks, Walisongo Semarang. This researcher talked the students of Vocational High School are about analysis content of reading materials in preparing for the world of work. It is mean in textbook and focused reading skills. Third Vocational High School that main focus on Yuanching Lee and Lihung Chang (2012) An productive skills such as writing and speaking, analysis of Speaking Activity Designs of Junior but it does not mean the English teacher ignore High School English Textbook used in Taiwan another skills.

and China published by National Pingtung Nowdays the Government has changed the University of Education. The writers talked 2006 curriculum (KTSP) become the 2013 about speaking activity and just focused in curriculum (K13). It means that, the teacher speaking skills. Fourth AriantiKurniasari(2009) have to arrange syllabus that be valid in each An Analysis Teaching Learning Activities Of school at Indonesia. Textbook that uses by the Speaking Skill In English Textbook For Second teacher to teach should be suitable with the Year Junior High School Based On The 2006 syllabus, which can raise the goal of the English Curriculum at University Of curriculum that use by the school. Besides that, Muhammadiyah Malang. Fifth Nuryantiningsi School Based Curriculum also deals with the Pusporini (2009) A Content Analysis on English four language skills in English, such as; e-Book for JuniorHigh School Grade VII, listening, speaking, reading, and writing. In "English in Focus" at Faculty of Letter State speaking, the Students are able to know and University of Malang. And the last Fatima understanding the content of speaking Setiawati(2010) A Content Analysis on (monologues, prologue, speeches, telling a "Wonderful World", an English Textbook for story and reading aloud). At Vocational High Eleven Graders of Senior High School at State School has a different about content of a new University of Malang.

curriculum from government, because the This section presented content analysis English vocational students have been preparing to textbook based on 2013 curriculum for the first face world of work. Actually in 2013 grade students at vocational high school 4 curriculum (K13) does not change too much Makassar.

but just there is a little increasing. In 2013 Content Analysis

curriculum there are the main competence, the Learning contents should be analysis in the light base competence, capacity learning, lesson and of the following with objectives, extent, tasks. relevance, degree of difficulty, available Furthermore, the researcher want to analyze sources, demands and requirements of the speaking material in English textbook as a syllabus, depth of study, classification, timecomparing to improving student' speaking scheduling, textbooks available, other available skill at vocational high school 4 Makassar.

learning content, suitability for relevant, and structure of the subject content, Carl et al in Arend E Carl (2009).

Speaking 
Speaking is often accomplished by In collecting the data, the researcher used communication activities and role plays in the English Textbook. Its refer to technique of classroom. However, most of the speaking is collecting data by gathering Speaking materials done by teachers. Moreover, many textbooks in English Textbook and analyzing documents, do not contain enough activities for speaking, while document is any communicable material which might be a reason why a lot of students used to explain some attributes of an object, have troubles with speaking and are very poor systems or procedures. It means that the in it, Grant in Lee (2012). qualitative data which is drawn with words and Textbook. According to Anshary and Babaii in sentences, clustered following its category to Setiawati(2010), a textbook is a framework gain conclusion.

which regulates and times the programs. A In doing the research, the researcher need some textbook provides ready-made teaching texts reference that related to the study. There aimed and learning tasks. Moreover, a textbook is the to help the researcher in analyzing the data. easiest and cheapest way of providing learning There are several steps that the researcher have materials. Curriculum is a plan that gives done in collecting the reference, as follows:

guidance in the teaching learning process activities. From the definition above, the Researcher concludes that curriculum is a plan that is developed to make teaching-learning activities progress well. It is kind of guidance in the teaching-learning process. The reformation of curriculum is sometimes done in order to improve or to develop the quality of In analyzing the data, the researcher used text education. The curriculum also contains analysis or discourse analysis as the technique. science, knowledge, and experience worth Discourse analysis is minimally the study of giving to the students to obtain the educational language in use that extends beyond sentence objectives.

boundaries. It means that discourse analysis is Theoretical framework below explains the concerned with the study of the relationship process of descriptive analysis of speaking between language and the context in which it is materials in the textbook. There are 4 stages used in this research. The calculation to known tospeaking of Vocational High School and the relevancy English textbook for the first then compare it to the speaking materials in grade students that used at Vocational High English textbook.

\section{RESEARCH METHOD}

The researcher that had presented in details the methodology of the research used in this study. It is divided into several sub chapters. They are research Design, Source of data, Research's Instrument, Data Collection and Procedure of analyzing data from English textbook that using for first grade student at Vocational High School 4 Makassar.

The instrument that used to analyze the data in this study is checklist. First, the checklist used to analyze the relevancy between speaking materials that founded in the textbook with the aspect of contents. Second, the checklist used to analyze the relevancy between speaking materials that founded in the textbook with the syllabus of curriculum 2013.
School 4 Makassar between 2013 syllabus, the researcher using percentages to determine the result this research.

\section{FINDINGS AND DISCUSSION}

The result of this research was divided to two parts. The first result shows the coverage of speaking material contents in textbook for The First Grade Students of Vocational High School 4 Makassar is in line with 2013 Curriculum syllabus. The second result shows the percentage of speaking material contents in Vocational High School 4 Makassar is in line with 2013 Curriculum syllabus are in line with 2013 Curriculum syllabus. There are 9 Chapters English material in English textbook. Especially speaking materials which will analyze in this chapter. All of these speaking materials are textbook for The First Grade Students Of 
collected from "Bahasa Inggris" for 10th grade of Vocational High School.

Table 1. The Relation Between Speaking Material in Syllabus of K13 and Textbook

$\begin{array}{cccc} & & \text { Title of } & \\ & \text { Speaking } & \text { Each } & \text { Speaking } \\ \text { N } & \text { Learning } & \text { Chapter } & \text { Learning } \\ \text { o } & \text { Syllabus } & \text { in } & \text { Material in } \\ & \left.\text { of } K 13^{*}\right) & \text { Textboo } & \text { Textbook }\end{array}$

\begin{tabular}{|c|c|c|c|}
\hline 1 & $\begin{array}{l}\text { Simple } \\
\text { oral and } \\
\text { written } \\
\text { texts to } \\
\text { describing } \\
\text { self and } \\
\text { ask for } \\
\text { identity } \\
\text { and } \\
\text { response. }\end{array}$ & $\begin{array}{c}\text { Talking } \\
\text { about Self }\end{array}$ & $\begin{array}{l}\text { 1. Talking } \\
\text { about } \\
\text { Self } \\
\text { 2. Introdu } \\
\text { ction } \\
\text { game: } \\
\text { Party } \\
\text { Time. }\end{array}$ \\
\hline 2 & $\begin{array}{l}\text { Oral and } \\
\text { written } \\
\text { texts to } \\
\text { praise and } \\
\text { response }\end{array}$ & $\begin{array}{l}\text { Complim } \\
\text { enting } \\
\text { and } \\
\text { Showing } \\
\text { Care }\end{array}$ & $\begin{array}{l}\text { Complimenting } \\
\text { and Showing } \\
\text { care divided to } \\
\text { Expressing } \\
\text { complimenting } \\
\text { and showing } \\
\text { care with the } \\
\text { dialog with } \\
\text { their friends. } \\
\text { 1. } \\
\text { Complementing } \\
\text { Dialog } \\
\text { a. } \\
\text { Complement } \\
\text { ing } \\
\text { b. Responses } \\
\text { 2. Showing } \\
\text { Care Dialog } \\
\text { a. Showing } \\
\text { Care } \\
\text { b. Responses }\end{array}$ \\
\hline & $\begin{array}{l}\text { Oral and } \\
\text { written } \\
\text { texts to } \\
\text { showing } \\
\text { care and } \\
\text { response }\end{array}$ & $\begin{array}{l}\text { Expressin } \\
\mathrm{g} \\
\text { Intention }\end{array}$ & $\begin{array}{l}\text { Expressing } \\
\text { Intention is } \\
\text { divided to make } \\
\text { a plans for } \\
\text { anything that } \\
\text { will they are to }\end{array}$ \\
\hline
\end{tabular}

Oral and Congratul written ating texts others express intentions and asked to perform an action / activity

Oral and written texts to express and ask for actions / events that do / happened ate and response do.

1. Expressing Intention with the dialog to make Holiday plans.

Congratulating others to divided the student to giving congratulation with their friend in every situation. For example in textbook give a speaking play, 'Let's play scissors, rock, and paper. The winner chooses for himself/herself a situation and the partner have to make an expressing of congratulation.

Oral and Describin We can written g People describe people texts to by these congratul following example: - Personality and appearance. - Clothing. Describing the places that interesting and not interesting had visited or other natural tourist object. The student have to describing the 


\begin{tabular}{|c|c|c|}
\hline $\begin{array}{l}\text { in the } \\
\text { past } \\
\text { which } \\
\text { refers to } \\
\text { the time }\end{array}$ & places. & $\begin{array}{l}\text { classmate about } \\
\text { the result of the } \\
\text { meeting with } \\
\text { OSIS. }\end{array}$ \\
\hline
\end{tabular}

of which

refers to

the end

Descripti Visiting The students

ve text Niagara have a pair

simple Falls work that try to

oral and

written

about

people,

tourist

attraction

$\mathrm{s}$, and

famous

historic

buildings

8

Announc

ement

1.Mention

Describin Ordering the

$\mathrm{g}$

Places

ment

purpose

2.Mention

detail

informati

on from

announce

ment

\begin{tabular}{|c|c|c|}
\hline $\begin{array}{l}\text { Text } \\
\text { recount } \\
\text { simple } \\
\text { oral and } \\
\text { written } \\
\text { about the } \\
\text { experienc } \\
\text { e / } \\
\text { activities } \\
\text { / events / } \\
\text { events }\end{array}$ & $\begin{array}{l}\text { Giving } \\
\text { Announc } \\
\text { ement }\end{array}$ & $\begin{array}{l}\text { This part of } \\
\text { chapter the } \\
\text { student in order } \\
\text { to imagine that } \\
\text { they are the } \\
\text { captain of their } \\
\text { class that attend } \\
\text { in meeting with } \\
\text { OSIS and have } \\
\text { to make an } \\
\text { announcement } \\
\text { to their }\end{array}$ \\
\hline
\end{tabular}

remember one interesting place they have visited and tell with their friends about the place. their parents or relatives about historical places that they are know.

1.What is the name of the places?

2. How old is the place? 3. Is the place spooky?

4. Why is it mysterious? 5. How does the place look like? students to ask
This table explained about how the relevancy speaking material in syllabus 2013 with speaking material in English textbook, to know how the different and the same things that which are contained in syllabus and English Textbook and as a Comparing speaking material in Syllabus 2013 and English Textbook.

In the end of this research's result, the compatibility percentage of the whole textbook material to $K 13$ syllabus is found by summing all the percentage of these 9 chapters and takes the mean percentage among them. To find the total speaking materials compatibility percentage of textbook to K13 syllabus, the researcher uses this formulation.

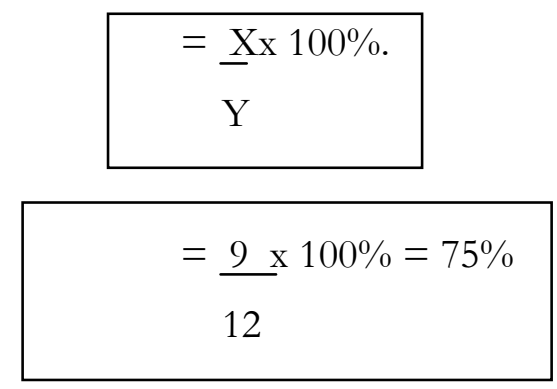

Note:

$$
\mathrm{X}=\quad \text { the total of criteria points which }
$$

were met in a workbook for each Chapters

aspect.

$\mathrm{Y}=\quad$ the total of criteria points in each sub aspect.

Therefore the writer found the 
compatibility percentage from all 9 chapters is 75\%. Textbook has 75\% similarity with K13.

This percentage is included from the similarity patterns between speaking learning material in Textbook to K13 syllabus.

learning as supplies for face to world work.

\section{CONCLUSION}

From the checklist table, the result shows the compatibility percentage of textbook's speaking materials to $K 13$ syllabus is $75 \%$. The

The textbook has not completely following points are the major findings of this fulfilled Relevance of the Materials to the research.

Curriculum. This was because, every chapters

The first point is the speaking materials in just had a little space for speaking activities, so "BukuBahasaInggris for the first grade students at that the researcher thinks, the student really Vocational High School" have a good relation to difficult to improve their speaking skills cause a the content of syllabus. There are; less speaking activities. In every chapters not to give the students to speaking with friends or improve the students' speaking skill.

There is in some chapters similarity in speaking activities namely in the chapter 5, 6,7, and 8 about Describing, for example in chapter
1. understanding basic expressions in social interaction in daily life

2. Expressing happiness and sympathy,

3. Making an announcement

4. Telling stories and experience (monologue).

5. The speaking tasks in the textbook are not 5 is describing people. Describing a tourism or well developed.

destination that interesting or not interesting and

In The textbook, most of the speaking describing historical places there are in chapter tasks are in Role Play activities. The textbook 6,7 and 8. The researcher thinks speaking does not give any speaking activities to increase activities that in English textbook as handbook the student understanding in speaking material. In and guiding for learning speaking does not content aspect, the textbook "Bahasa Inggris" is variety. For another chapters a bit different than lacking in terms of transactional texts because it just describing things. does not give enough opportunities for the

In chapter 1, 2, 3, 4, and 9 are over to students to communicate interpersonally. It has produce expression in speaking. Actually this sufficient explanation on the expressions required textbook on every chapters have a speaking to produce certain interpersonal texts and activities but those could not covering speaking' provides sufficient model texts, but it has very need who can really improve the students' few speaking activities which should speaking skill. Even less the English teacher who enable the students to make interpersonal had Interview by the researcher before took this communication and make the students improve thesis, that said if the graduated student from speaking skill.

Vocational High School have to have comprehend with productive skills in English 


\section{SUGGESTION}

First, the speaking material explanation
Ed.2005

Lee, Yuanchinget al. An Analysis of Speaking Activity Designs of Junior-High.

in The textbook should be developed by the School English Textbooks Used in Taiwan and

teacher. In the case that some chapters in The

China.NationalPingtungUniversiy

ofEducation.2012

textbook does not give any explanation about Sholichatun, Siti. 2011content Analysis Of

the materials content, the English teacher should

be creative to provide the explanation, refers to

develop the students' understanding about the

material. It is better to the teacher to give the

explanation of the speaking materials' content,

as the basic knowledge, to the students before Brown, Douglas. Language assessment; principles

giving the tasks.

Reading Materials In English On Sky

Textbook For Junior High School.

Walisongo State Institute For Islamic

Studies semarang.2011

Madecorivá,Ivana. TheproportionOf Language

Skills In English Textbooks At Lower

Secondary Schools. Masaryk University

Faculty Of Education.2013 and Classroom pratices. New york: Pearson Education.2004

Second, the teacher should provide more Thesis (online).Textbook and Curriculum related vocabulary knowledge that can develop Analy 2015.

students' skill in produce speaking. Besides, the http://zulkarnaenjafar.blogspot.com/2009/07/te

teacher can develop the grammar use in speaking in case to increase the students' understanding of grammar. Both of vocabulary knowledge and grammar use in speaking can boost the students' fluency to speak.

Third, the teacher is suggested to modify the speaking tasks. Since most of the speaking tasks in The textbook is role playing, teacher can xtbook-and-curriculum-analysis.html.2009 Grant, N. Making the Most of Your Textbook. Essex, England: Longman Group UK Limited.1987

Joseph A. Maxwell. Qualitative Research Design, London: SAGE Publication.1996

Kementrianpendidikandankebudayaan.Kerangka DasardanKurikulum 2013. Jakarta: Kemendikbud.2013

Kurniasari, Arianti.An Analysis Teaching Learning Activities Of Speaking Skill In English Textbook For Second Year Junior

provides another speaking tasks, such as brainstorming, storytelling, interviews, and High School Based On The 2006 English simulation. These different tasks can give more Curriculum. University Of Muhammadiyah Malang.2009

challenges for students' activities. The activity or Wahyuningsih, Niken. An analysis of Reading task should not be given in repetition way. It should be in multi task form. material in Textbook English in focus for grade VII Junior High School. Department of National Education.2014

\section{REFERENCES}

Arikunto, Suharsimi,

ProsedurPenelitianSuatuPendekatanPraktik, Jakarta: Rineka Cipta,6th Ed.2006

Ferris, Dana and Hedgcock, John S., Teaching ESL Composition: Purpose, Process, and Practice, London, USA: Laurence Erlbaum Associates, $2^{\text {nd }}$

Syafniar, RusdaAyu. The Analysis Of The Reading Materials In "English Alive" Textbook Based On School based

Curriculum For Second Grade Students Of Senior High School.Department Of English Education Faculty Of Tarbiyah And Teacher Training SyarifHidayatullah State Islamic University.2014 David J. Flinders and Stephen J Thornton., The 
Curriculum Studies Reader,Newyork, UK:

Routledge, $3{ }^{\text {rd }}$ Ed.2009

Carl, E Arend., teacher emprowerment through curriculum development., Cape town, South Africa: Juta and Company Ltd, $3^{\text {rd }}$ Ed.2009

Setiawati, Fatima., A Content Analysis on "Wonderful World", an English Textbook for Eleven Graders of Senior High School.

Malang: State University of Malang.2010

Cunningsworth, A., Choosing your Course book,

UK: Heinemann English Language

Teaching. 1995

Pusporini, Nuryantiningsih.. 2009. A Content Analysison English e-Book for JuniorHigh School Grade VII, "English in Focus." Malang: Faculty of Letter State University of Malang.

Neuendorf, Kimberly A. 2002. The Content Analysis Guidebook. United States of America: Sage Publications, Inc.

Stemler, Steve (2001). An overview of content analysis.Practical Assessment, Research \& Evaluation. Yale University 